\title{
Stillingsstrukturens betydning for samspillet mellem forskning og undervisning
}

Frederik Voetmann Christiansen, lektor, ph.d. (scient.), Social and Clinical Pharmacy og Institut for Naturfagenes Didaktik, Københavns Universitet.

\section{Reviewet artikel}

Universiteternes stillingsstruktur har betydning for, hvordan universiteterne kan varetage undervisning og forskning - herunder sikre samspillet mellem hovedopgaverne. Artiklen kortloegger, hvordan de 5 stillingscirkulaerer, der har voeret fra 1994 til i dag, har ført til forskydninger i ansaettelsespraksis på universiteterne i retning af relativt flere midlertidige stillinger med altovervejende fokus på forskning. Det konkluderes, at der er behov for et fornyet politisk fokus på, hvordan samspillet mellem forskning og undervisning kan styrkes, og på at stillingsstrukturen er et vigtigt sted at saette ind.

Universiteternes hovedopgaver er at "drive forskning og at give forskningsbaseret uddannelse" (Universitetsloven, §2). Videre lyder det i §2, at "Universiteterne skal sikre et ligeværdigt samspil mellem forskning og undervisning". Beskrivelsen af universiteternes hovedformål som forskning og uddannelse i samspil har en lang historie på universitetet og skal ses i lyset af grundlæggende humboldtske principper (Bärenholdt, 2014, s. 18). Hovedopgaverne er fremgået af universiteternes styrelsesdokumenter, i hvert fald siden centraliseringen med Styrelsesloven af 1970, og tankegodset går meget længere tilbage.

Fra et styringsperspektiv er samspillet mellem forskning og undervisning sikret på to måder. For det første er de ansatte (som hovedregel) ansat til både at forske og til at undervise. For det andet finansieres universiteterne gennem en basisbevilling som institutionerne kan anvende frit inden for formålene (jf. Universitetsloven §§19-21). I de senere år har der været stor politisk opmærksomhed på universiteternes basisbevillinger og på, hvordan dette system har ændret sig over tid i takt med nye politiske forventninger til universiteterne (se fx Aagaard, 2011). Stillingsstrukturen har ikke fået den samme opmærksomhed.

Der er næppe noget, der betyder mere for, hvordan universitetsansatte agerer i forhold til hovedopgaverne, end den stillingskategori, de er ansat i. Det præcise stillingsindhold og arbejdsopgaverne er beskrevet i stillingsopslaget, men til grund for disse beskrivelser ligger cirkulærer, der definerer forskellige typer ansattelser, og som definerer hovedopgaver og kvalifikationskrav for de forskellige stillingstyper. 
Stillingskategorierne foreskriver bestemte typer adfærd for den ansatte, herunder hvordan de forskellige opgaver i stillingen skal prioriteres i forhold til hinanden. Desuden er der et hierarki mellem stillingerne, som giver de ansatte relevante pejlemærker i forhold til, hvordan de skal prioritere i forhold til evt. forfremmelse.

Det er disse forhold jeg vil drøfte i denne artikel. Specifikt vil jeg kigge på, hvordan stillingsstrukturerne for universiteterne har ændret sig over tid med hensyn til universiteternes to hovedopgaver: Hvordan beskrives kvalifikationskravene og de ansattes arbejdsfunktioner med hensyn til undervisning og forskning i de mest anvendte stillingstyper? Jeg vil ikke drøfte de mere specielle stillingskategorier men kun de kategorier, som benyttes bredt.

Stillingscirkulærerne forhandles mellem ministeriet og Akademikernes Centralorganisation, og der har inden for de seneste 25 år været fem revisioner. Andringerne er ofte sket i forbindelse med eller i forlængelse af større ændringer i Universitetsloven eller andre ændringer i organiseringen af universiteterne.

Cirkulærerne for stillingsstruktur for videnskabeligt personale har to dele. Dels er der selve cirkulæret, som beskriver stillingsstrukturen ret overordnet, dels er der tilknyttet et notat til cirkulæret. I notatet gives baggrund for og uddybning af cirkulærets bestemmelser, og det er ofte i notatet at intentionerne med cirkulæret fremgår. Mit fokus er på, hvordan de konkrete ændringer, der er lavet i stillingscirkulæret, har ført til ændringer i universiteternes ansættelsespraksis og deres varetagelse af hovedopgaverne. Jeg vil altså ikke blot analysere ændringerne i cirkulærerne men forsøge at opridse, hvad ændringerne førte med sig i forhold til ændret ansættelsespraksis. Til støtte for analysen har jeg især lænet mig op ad de rapporter, som Uni-C løbende har udarbejdet om udviklingen i medarbejderstaben (Ståhle 2003; 2005; 2007; 2011; 2014a; 2014b), samt data fra Moderniseringsstyrelsens forhandlingsdatabase.

\section{Stillingscirkulæret 1993: Styrkelse af undervisning}

I cirkulæret om stillingsstruktur fra 1993 skelnedes mellem tre overordnede kategorier af ansatte: Underviserstillinger på deltid, ordincere ansœttelser (adjunkt, lektor, professor) og supplerende anscttelser. De supplerende ansættelser var enten rene forskningsstillinger eller rene undervisningsstillinger (sidstnævnte var der ret få af). Forskningsstillingerne var tidsbegrænsede stillinger, hvoraf nogle var meget kortvarige. Væsentligst i gruppen var kategorierne forskningsadjunkt, forskningslektor og forskningsprofessor - alle med en maksimal ansættelsestid ved samme institution på 5 år.

Skellet mellem underviserstillinger på deltid, ordinœere stillinger og supplerende stillinger signalerede en normal praksis, og noget der lå uden for den. Denne praksis var at de ordinære ansatte var i stillinger, der indebar såvel forskning som undervisning (speci- 
fikt: adjunkt, lektor, professor). Dertil kom så nogle "unormale", der var ansat i tidsbegrænsede forskningsstillinger.

Det afgørende nye i forhandlingen af stillingscirkulæret i 1993 var, at der for første gang blev stillet krav til den pædagogiske uddannelse af ansatte i adjunktkategorien.

I notatet fremgår det, at "I forhold til de undervisningsmæssige opgaver skal institutionen sikre, at adjunkten får systematisk supervision og vejledning, der afsluttes med en skriftlig vurdering af adjunktens undervisningsmæssige kvalifikationer". Denne formulering går nærmest ordret igen i alle efterfølgende cirkulærer. Kravene til pædagogisk uddannelse blev beskrevet som et kvalifikationskrav i forbindelse med ansættelsen af lektorer, dog sådan at de forskningsmæssige kvalifikationer vægtedes højest:

"Ved bescttelse of (lektor-)stilling skal hovedvaegten loegges på en vurdering af ansøgerens forskningsmassige kvalifikationer. Samtidig skal der foretages en vurdering af, om ansøgerne har tilfredsstillende undervisningsmassige kvalifikationer. For adjunkter, der søger lektoranscettelser, forudscettes vedlagt vurdering af undervisningsmaessige kvalifikationer".

Stillingscirkulæret markerede dermed en væsentlig opprioritering af undervisningen, men der var ikke tale om en sidestilling af forskning og undervisning - tværtimod blev det understreget, at hovedvægten i bedømmelsen af lektorer og professorer skulle lægges på forskningen. I forhold til ansættelse af lektorer, der ikke havde tilstrækkelige undervisningskvalifikationer, var der en mulighed for at blive ansat som lektor på prøve: "Har den pågældende ikke forud for ansættelsen som lektor opnået tilstrækkelig undervisningserfaring, kan lektoransættelsen ske på prøve for en periode indtil 111/2 år" (Stillingscirkulære, 1993).

I forlængelse af stillingscirkulæret vedtog Rektorkollegiet i 1997 fælles retningslinjer for pædagogisk uddannelse af adjunkter på de højere uddannelsesinstitutioner (Rektorkollegiet, 1997), og i årene derefter begyndte adjunktuddannelserne at indrette sig efter retningslinjerne.

Parallelt med denne løbende styrkelse af undervisningen foregik der en anden udvikling i perioden 1993-2000. Antallet af ansatte i den supplerende stillingsstruktur specielt kategorien forskningsadjunkt - steg kraftigt. Antallet af forskningsadjunkter oversteg omkring år 2000 antallet af ordinære adjunkter.

Ser man på opgørelser af antallet af ansatte i ordinære (faste) stillinger og antal ansatte i de tidsbegrænsede forskningsstillinger ved udgangen af år 2000, er forholdet mellem VIP med både forskning og undervisningsforpligtelse og tidsbegrænset ansatte i forskningsstillinger ca. 5:1 (altså 5 ansatte i stillinger med både forskning og undervisning for hver 1 ansat i en ren forskningsstilling) (Beregning baseret på tal i Ståhle, 2005). 


\section{Stillingscirkulæret 2000: Styrkelse af undervisning}

I år 2000 kom et nyt stillingscirkulære, med forskningsminister Birthe Weiss som afsender. Cirkulæret blev til efter hårde forhandlinger mellem de faglige organisationer og ministeriet med sammenbrud undervejs. En ambition fra ministeren var, at undervisningens status skulle styrkes. Weiss skrev i en vred kronik om de sammenbrudte forhandlinger:

"Universitetsundervisningen skulle generelt opgraderes. Jeg ønskede at ligestille forsknings- og undervisningskvalifikationer for lektorer, og jeg så gerne, at det meget store undervisningsfrikøb blev mindsket. Derfor skulle den supplerende forsknings-stillingsstruktur sammenloegges med den ordincere. I dag er der fx halvanden gang så mange forskningsadjunkter som adjunkter - 650 mod 440. Forskningsadjunkter underviser typisk ikke, og de skal ikke gennemgå det såkaldte adjunktpaedagogikum. Hvad indeborer det? Det kan i hvert fald betyde, at undervisningsaktiviteter allerede fra begyndelsen af en universitetskarriere får et sekundastempel på sig. At det eneste, der toeller, er antallet af strikt videnskabelige publikationer. Her er fortidens skygger stadig lange nok til at indhente os. Men det er ikke en del af min vision. En sammenlagning af de to strukturer ville derudover betyde, at alle ansatte principielt blev ligestillet. At de alle er med til at sikre løsningen af alle opgavetyper. Ingen skulle på forhånd vore taget fra til kun at kunne forske. Nogle vil måske synes, at det er en paradoksal holdning for en forskningsminister. Jeg ser det selv som et udtryk for konkret solidaritet" (Weiss, 1999).

Mange af ministerens ønsker kan findes i det cirkulære, der blev vedtaget. I notatet står der, at de overordnede mål med ændringen var at skabe "bedre og mere attraktive karriereforløb på universiteterne, der kan fremme fornyelse og sammenhæng mellem forskning og uddannelse, blandt andet gennem en forsimpling af strukturen" (Stillingsstruktur, 2000). De forskningsrettede stillinger, forskningsadjunkt, -lektor og -professor, blev nedlagt. I de ordinære stillingers beskrivelse blev det fastholdt at hovedopgaverne var både forskning og undervisning, men der blev åbnet op for at balancen for den enkelte kunne variere over tid.

Ikke uvæsentligt førte denne ændring til, at der åbnedes for, at lektor- og professorkategorierne kunne være tidsbegronsede - tidligere blev disse stillinger beskrevet som varige men nu lød det, at "Ansættelsen er tidsubegrænset, med mindre andet er bestemt ved ansættelsen". Det må antages, at denne ændring hang sammen med, at de tidligere tidsbegrænsede forskningsstillinger nu skulle kunne omfattes af mere rummelige kategorier, men det kan undre, at denne ændring ikke gav anledning til mere offentlig debat, da der var principielle grunde til, at disse stillinger var beskrevet som varige (jf. det amerikanske princip om 'tenure'). 
Hvad angik adjunkturerne kunne institutionerne nu opslå adjunkturer hvor hovedvægten lå på forskning og udviklingsarbejde i op til tre år. Evt. forlængelse herudover skulle i givet fald indebære, at adjunkten fik undervisningsopgaver og tilhørende pædagogisk supervision og udtalelse.

I kvalifikationskravene til lektorer skærpedes kravene til undervisningskvalifikationer, så det kom til at ligne en ligestilling mellem hovedopgaverne. Således lød formuleringen nu:

"Ved bescettelse af stillingen skal det sikres, at både ansøgers forskningsmaessige og undervisningsmaessige kvalifikationer er på det ønskede niveau. Begge kvalifikationer indgår tilsammen med en hovedvaegt i helhedsvurderingen".

Det specificeredes, at ansøgere skulle fremlægge dokumentation for undervisningsmæssige kvalifikationer, som kunne danne grundlag for bedømmelsen af undervisningsmæssige/pædagogiske kvalifikationer (jf. Christiansen \& Troelsen, dette nummer). Der var fortsat mulighed for ansættelse som lektor på prøve ved manglende undervisningskvalifikationer.

Også kvalifikationskravene til professorers undervisningskompetence skærpedes. I 1993-notatet fremgik det, at undervisningskvalifkationer skulle vægtes i bedømmelsen, og at:

"Der forudscettes normalt en tilfredsstillende indsats inden for det undervisningsmaessige område. Saerligt kvalificeret indsats og nyudvikling på dette område skal vaegte i den samlede vurdering ved bescettelse af stillingen."

I 2000-notatet lyder det skarpere, at det skal

"sikres, at ansøgeren har fyldestgørende kvalifikationer til at varetage undervisning. Saerlig indsats og nyudvikling på det undervisningsmaessige område skal vaegtes i den samlede vurdering ved bescttelse af stillingen."

Med stillingscirkulærets sammenlægning af de ordinære stillingskategorier og de mere rummelige kategorier, blev det vanskeligere at skelne mellem "ordinære" adjunkter, lektorer og professorer og ansatte med hovedvægt på forskning (typisk i tidsbegrænsede stillinger). Et mål for dette kan dog estimeres gennem antallet af eksternt finansierede ansatte, da de fleste ansatte, der var ansat primært til forskning og udvikling, var eksternt finansierede (ifølge Ståhle, 2004). Det er dermed muligt at anslå forholdet mellem antallet af ordinært ansatte (dvs. ansat til både forskning og undervisning) og supplerende ansatte (dvs. ansat primært til forskning og udvikling). Dette giver et forhold på ca. 5:1 i lighed med forholdet i 2001 (Ståhle, 2003). Der var med andre ord ikke nogen alarmerende udvikling i forholdet mellem ansatte på ordinære vilkår og ansatte på supplerende vilkår i perioden. Tværtimod så cirkulæret ud til at virke efter hensigten: At få dæmmet op for antallet af forskningsadjunkter der ikke kvalificerede sig undervisningsmæssigt. 


\section{Stillingscirkulæret 2005: Svækkelse af undervisningens status}

Det næste stillingscirkulære blev forhandlet mellem videnskabsminister Helge Sander og de faglige organisationer. Regeringens målsætning for revisionen var at skabe en mere fleksibel struktur, hvor særligt universiteternes samspil med erhvervslivet kunne gøres lettere. I rapporten Nye veje mellem forskning og erhverv - fra tanke til faktura skitseredes regeringens mål for en ny stillingsstruktur. Her argumenterede regeringen for, at universiteterne skulle have større frihed og fleksibilitet i ansættelsen af forskere, herunder bedre muligheder for at rekruttere fra erhvervslivet (Regeringen, 2003, s. 20). Blandt de væsentlige ændringer i stillingsstrukturen var, at adjunkturet blev udvidet til at være 4-årigt. Der blev åbnet op for, at der kunne laves oprykning af adjunkter - altså, at der kunne opslås tidsubegrænsede adjunkturer, hvor adjunkten kunne overgå til lektorat efter bedømmelse uden opslag.

En anden væsentlig, for ikke at sige afgørende, ændring var, at der oprettedes en ny kategori: 'Postdoc'. Postdoc-stillingen var en forskningsstilling med en varighed på indtil 3 år og kunne rumme undervisning i et "vist omfang". Kategorien kunne bruges "hvor universitet har behov for at ansætte en ph.d. som postdoc, eller hvor der skal varetages tidsbegrænsede forskningsopgaver." Der var mulighed for genansættelse, men kun 3 år ved samme institution.

Reelt set var (eller blev) den nye kategori en erstatning for kategorien "forskningsadjunkt", som den fandtes før år 2000 i den supplerende stillingsstruktur. Det fremgik ikke af cirkulæret, om postdoc'er skulle modtage supervision og pædagogisk opkvalificering, men det har næppe været tanken. Birthe Weiss' ambition om at sikre, at forskningsadjunkter også skulle kvalificere sig på undervisning, blev således rullet tilbage med dette stillingscirkulære, men kategorien gjorde det langt lettere for universiteterne at tilknytte forskere i eksternt finansierede forskningsprojekter uden at forholde sig til at involvere dem i undervisning, deltage i pædagogisk uddannelse osv. Og kategorien var mere fleksibel i forhold til længden af ansættelsen end den tidligere (forsknings-) adjunkt.

I forhold til kvalifikationskravene til lektorer forsvandt de specifikke formuleringer om vurdering af undervisningskvalifikationer og beskrivelsen af, at begge skulle indgå med "hovedvægt i bedømmelsen". I 2004-cirkulæret står blot at

"En ansøger til et lektorat bedømmes på de kvalifikationer, der fremgår af stillingsopslaget. De forsknings- og undervisningsmaessige kvalifikationer skal svare til det niveau, der kan opnås på grundlag af en tilfredsstillende gennemført ansaettelsesperiode som adjunkt, men vil også kunne opnås på anden måde."

Tilsvarende forsvandt henvisninger til kvalifikationer inden for undervisning i bedømmelsen af professorer. I stillingscirkulæret fra 2000 fremgik det som nævnt, at det skulle sikres, at "ansøger har fyldestgørende undervisningskvalifikationer", og at særlige indsatser og nyudvikling skulle gives vægt i bedømmelsen. I 2004-strukturen 
er disse passager helt udgået. Selvom det fremgår klart, at undervisning er en del af stillingsindholdet for professorer, stod der intet om, at undervisningen skulle gives prioritet ved ansættelsen.

Indførelsen af postdoc-kategorien må betegnes som en meget dramatisk udvikling. Allerede i slutningen af 2006, kun to år efter cirkulæret var trådt i kraft, var der ansat mere end tusind personer i kategorien, og adjunktkategorien var skrumpet markant. Ved udgangen af 2006 var forholdet mellem ordinært ansatte og supplerende ansatte faldet til 3:1 (baseret på opgørelser i Ståhle, 2007).

"Oprykker"-adjunkturer - dvs. adjunkter ansat i stillinger, der ikke skulle opslås men bedømmes uden opslag, kom aldrig rigtigt til at fungere på grund af universiteternes tilbageholdenhed med at bruge kategorien.

\section{Stillingscirkulæret 2007: Status quo}

Stillingscirkulæret 2007 blev til som følge af universitetsfusionerne, og særligt fusioneringen af sektorforskningsinstitutionerne med universiteterne, der ledte til sammenlægning af stillingsstrukturerne for de to typer organisationer. Der skelnedes nu mellem fem niveauer, hvor de tre midterste svarer til de tidligere hovedstillinger i stillingsstrukturen:

\section{- Stillinger under adjunktniveau}

- Stillinger på adjunktniveau: Adjunkt, forsker og postdoc

- Stillinger på lektorniveau: Lektor og seniorforsker

- Stillinger på professorniveau: Professor m.fl.

\section{- Særlige stillinger}

For postdoc-kategorien blev det med dette cirkulære specificeret, at der ikke indgår pædagogisk opkvalificering, og at ansættelse som postdoc derfor ikke alene kan kvalificere til ansættelse som lektor/seniorforsker. Ud over at indføje stillingskategorierne fra sektorforskningsinstitutionerne indeholdt dette stillingscirkulære ingen større ændringer ift. 2004-cirkulæret.

Udviklingen fra 2007 til 2009 udviser da også samme tendens som udviklingen fra 2004 til 2007: At forholdet mellem ansatte i ordinære og i supplerende ansættelser blev mindre. Uanset om antallet af ansatte i kategorierne sektorforsker og forsker medregnes til de ansatte, der ikke har undervisningsopgaver, eller ej, og uanset om de eksternt finansierede adjunkter medregnes eller ej, kan forholdet mellem ordinære ansatte og forskningsansatte beregnes til at ligge i omegnen af 2:1 (beregning baseret på Ståhle, 2011). 


\section{Stillingsstrukturen 2013: En styrkelse af undervisningens status}

Revisionen af stillingsstrukturen i september 2013 er den seneste, og der ligger et ret besynderligt forløb bag dens ikrafttræden. Normalt følges cirkulære og notat ad, men for dette cirkulære har der været et alternativt forløb. I september 2013 trådte cirkulæret formelt i kraft, og det tilhørende notat blev udgivet (Notat om stillingsstruktur, 2013) - men selve cirkulæret manglede! På ministeriets hjemmeside blev notatet fremlagt sammen med et Q\&A-dokument og et følgebrev om intentionerne i cirkulæret. Først i september 2015, to år efter cirkulærets formelle ikrafttræden blev selve cirkulæret offentliggjort (Stillingsstruktur, 2015). I den mellemliggende periode har universiteterne derfor måttet agere efter de retningslinjer der var udstukket $\mathrm{i}$ notatet og i øvrigt henholde sig det gamle cirkulære fra 2007.

Intentionen med ændringerne i cirkulæret var bl.a. at synliggøre karriereperspektiver og at tydeliggøre balancen mellem universiteternes hovedopgaver. Konkret er dette gjort ved at adskille postdoc-stillingerne fra adjunkt/forskerstillingerne og ved at indføre et nyt 6-årigt "tenure track-adjunktur" (altså en udvidelse af det allerede eksisterende oprykker-adjunktur). Det såkaldte tenure track-adjunktur blev indført efter ønske fra universiteterne, med henblik på at kunne tiltrække internationale topforskere. Det understreges, at formålet med postdoc-stillingen er forskning, ikke undervisning, og at "Stillingen kan kvalificere til en karriere i det private erhvervsliv eller andre sektorer uden for universitetet. En ansættelse som postdoc kan også kvalificere til en efterfølgende ansættelse som adjunkt/forsker." Idéen bag cirkulæret har altså bl.a. været at standse den trafik, der har været af ansatte, der gik direkte via postdoc-stilling(er) til lektorat. I perioden 2013 til 2015 er det dog tvivlsomt, om universiteterne har taget denne intention alvorligt. Det skyldes blandt andet den mulighed, der var i 2007-cirkulæret, for at ansætte en 'lektor på prøve'. Man kunne altså kvalificere sig forskningsmæssigt gennem postdoc-ansættelser, blive ansat som 'lektor på prøve', og herefter kvalificere sig undervisningsmæssigt (herunder tage adjunktuddannelsen). Denne kattelem har eksisteret i alle stillingsstrukturerne siden 1993 - men den er ikke at finde i det nye cirkulære fra september 2015. Ved manglende undervisningskvalifikationer er der tilsyneladende nu ingen mulighed for at blive ansat i et lektorat. Muligheden for merit for tidligere ansættelse som postdoc i adjunkturer er også fjernet.

På figur 1 gengives hovedtræk i ændringerne i perioden fra 1993-2015. 


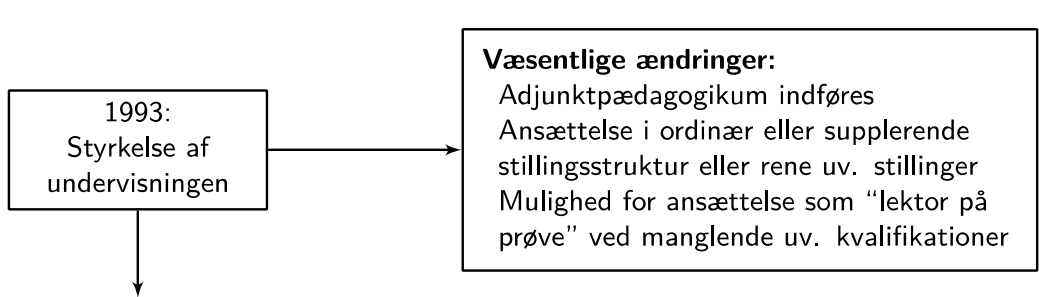

Rektorkoll. rapport om

adjunktpæd. (1997)

Stor stigning i antal forskningsadjunkter

Forholdstal (ult. 1999): ca. 5:1

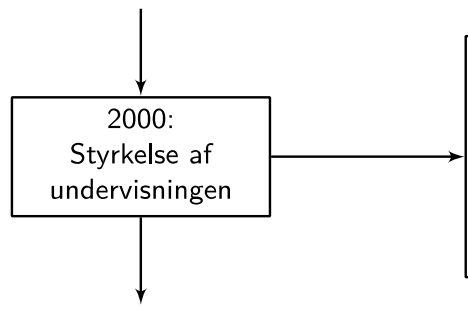

Væsentlige ændringer:

Rene forskningsstillinger afskaffes

Skærpede krav til undervisningskval. for

lektor og professor

Professor og lektorstilling kan være

tidsbegrænsede

Forholdstal (ult. 2004): ca. 5:1

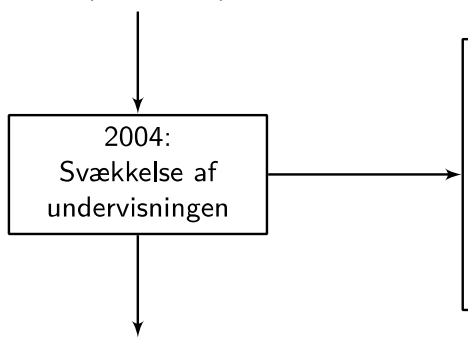

Væsentlige ændringer

Indførsel af Postdoc-stillingen

Mulighed for "oprykker" adjunktur

Svækkelse af krav til undervisningskval.

for lektor og professor

Bedre mulighed for ansættelse af lektorer

med "tilsvarende" kvalifikationer

Stor stigning $\mathrm{i}$ antal postdoc

Stor stigning i antal Ph.d. studerende

Forholdstal (ult. 2006): ca. 3:1

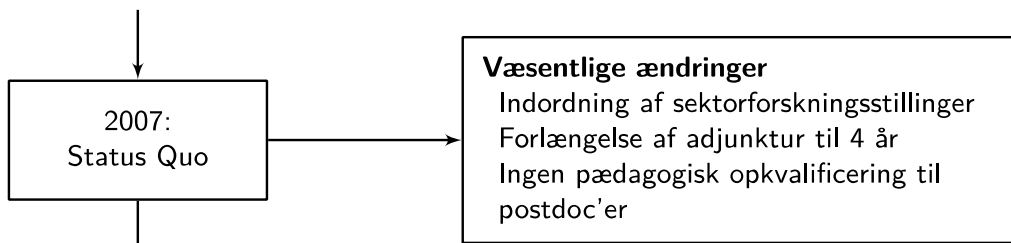

Fortsat kraftig stigning $i$ antal postdoc

Fortsat stigning $i$ antal Ph.d. studerende

Forholdstal (ult. 2009): ca. 2:1

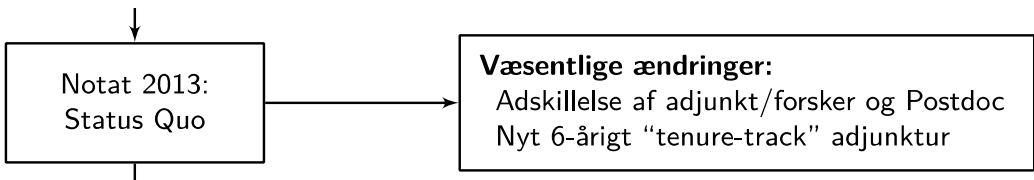

Stabilisering af antal postdoc?

Stabilisering af antal Ph.d. studerende?

Forholdstal: ?

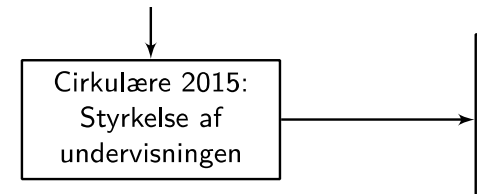

Væsentlige ændringer:

Afskaffelse af "lektor på prøve"

Ingen merit for tidl. ansættelse som

postdoc i adjunktur

Figur 1: Overblik over udviklingerne i stillingsstrukturerne. 
Der er næppe tvivl om, at universiteterne er begyndt at besinde sig på anvendelsen af postdoc'er. I de senere år har universiteterne faktisk ansat flere adjunkter (jf. figur 2). Det kraftigt øgede optag af studerende siden 2007 og stillingsnotatet fra 2013 har sandsynligvis haft en vis betydning for denne udvikling.

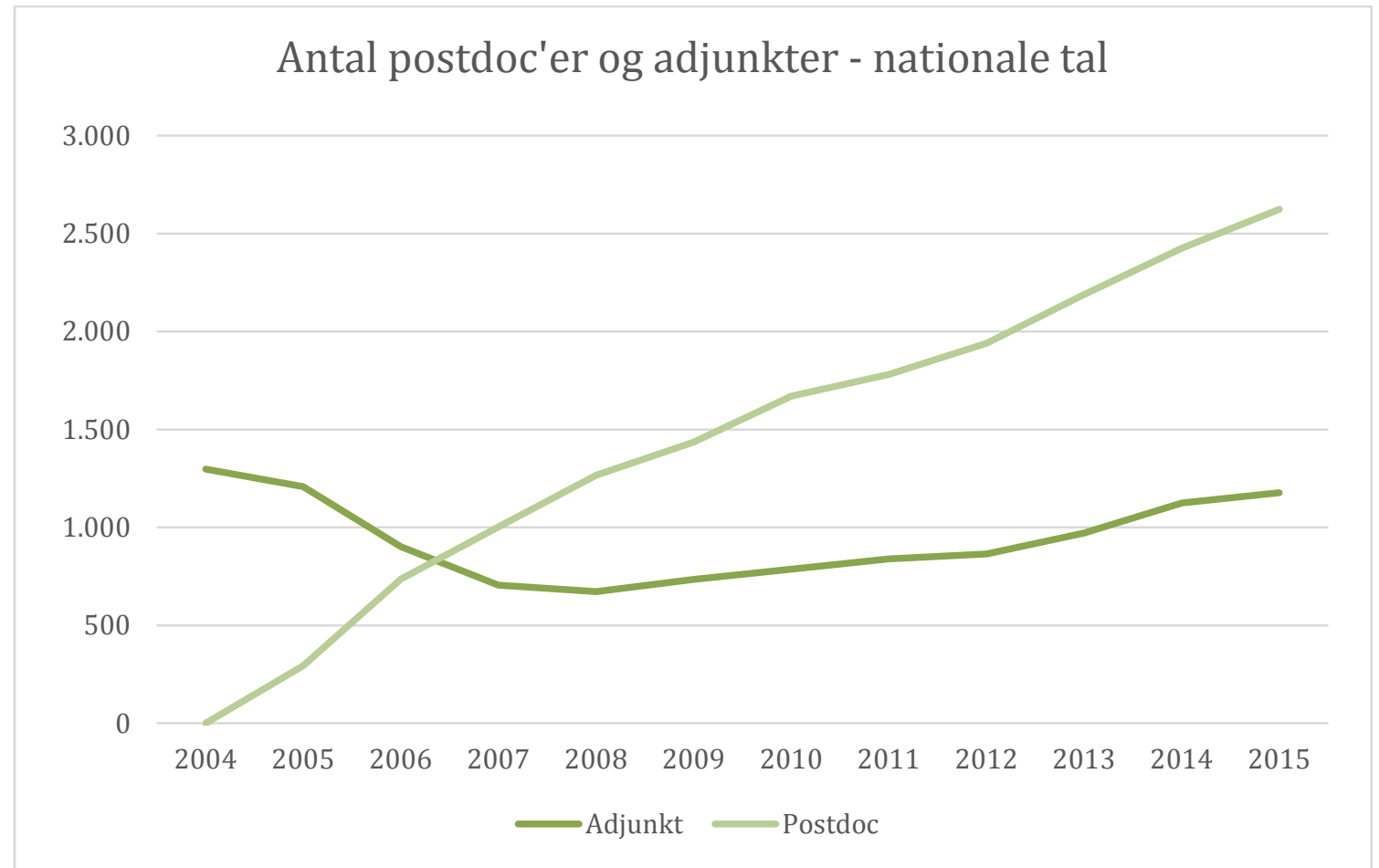

Figur 2: Udvikling i antal postdoc'er og adjunkter i universitetssektoren. Kilde: Moderniseringsstyrelsens forhandlingsdatabase.

\section{Diskussion}

De faglige organisationers ambition har forud for forhandlingerne altid været ambitionen om skabe flere faste stillinger. Dette har været en fiasko, hvis man ser på perioden som helhed. Tværtimod er der kommet mange flere løse stillinger i forhold til faste, og særligt i perioden fra 2005 til omkring 2011. Det skyldes især to forhold:

- At der er tilkommet mange nye ansatte i kategorien postdoc - stillingskategorien blev først etableret i 2005, og der er nu næsten ca. 2600 ansatte i stillingskategorien (2. kvartal 2016) mod ca. 1200 adjunkter.

- At universiteterne i stigende grad er begyndt at ansætte lektorer i tidsbegrænsede stillinger. Ståhle (2014) angiver at ca. 21\% af ansættelserne i lektorater i 2011-2013 var tidsbegrænsede. Muligheder for at ansætte lektorer og professorer i tidsbegrænsede stillinger blev indført i forbindelse med stillingscirkulæret fra år 2000. Er ambitionen om at styrke undervisningen ad denne vej blevet indfriet? Næppe. Den mulighed blev spoleret ved introduktionen af postdoc-kategorien i 2005. Men forholdet, at professorer og lektorer ikke længere havde varige stillinger, står tilbage. 
Forskydningerne peger (sammen med det øgede ph.d.-optag) samlet i én retning: En styrkelse af forskningen i forhold til undervisningen. Siden år 2005 er der sket meget store stigninger i stillingskategorier, hvortil der kun er knyttet undervisning i begrænset omfang. Årsagerne til disse forskydninger ligger selvsagt ikke alene i stillingsstrukturen, men også i det øgede fokus, som er givet til konkurrenceudsatte midler i den samme periode. Medfinansiering til eksternt finansierede projekter gennem basismidlerne har lagt yderligere pres på de medarbejdergrupper, der i praksis skal sikre samspillet mellem undervisning og forskning: Adjunkter, lektorer og professorer. De seneste nedskæringer på universiteterne (2016) tilfører yderligere benzin til det bål - nedskæringerne vil af naturlige årsager ramme de VIP'er der sidder i faste stillinger og som dermed indgår centralt i undervisningen.

Ved fremtidige revisioner af stillingscirkulæret har analysen peget på nogle centrale forhold, som jeg mener, bør overvejes nøje ved fremtidige revisioner:

- Når postdoc-stillingen ikke i sig selv er kvalificerende til lektoransættelse på universitetet, hvorfor ansættes der så fortsat så mange i denne type stillinger (jf. figur 2)? Er en ph.d.-grad ikke tilstrækkeligt til at dække erhvervslivets og andre sektorers behov? Reelt dækker kategorien over universiteternes ønske om at kunne ansætte folk i midlertidige forskningsstillinger, men kategorien er undergravende for sammenhængen mellem forskning og undervisning og er blevet en blidgyde for de ansatte i den. Bør man ikke simpelthen tage konsekvensen og afskaffe denne kategori? Dét vil i hvert fald bidrage til en stærkere kobling mellem forskning og undervisning og vil medføre, at fx de statslige forskningsråd bliver nødt til at forholde sig, ikke alene til forskningen, men også til samspillet mellem forskning og undervisning.

- Der har været en kraftig stigning i antallet af tidsbegrænsede lektorater i de senere år, også selvom disse beskrives som "normalt varige". Er dette en tilsigtet og ønskværdig udvikling?

\section{Konklusion}

De seneste 25 år har givet anledning til markante forskydninger i ansættelsespraksis på universiteterne i retning af relativt flere midlertidigt ansatte, der er ansat primært til varetagelse af forskningsopgaver.

Der er behov for politisk fokus, herunder fra universiteterne selv, på, hvordan samspillet mellem forskning og undervisning kan styrkes, og ikke blot på, hvordan de to hovedopgaver (tilsyneladende) kan styrkes hver for sig.

At sikre et frugtbart samspil mellem forskning og undervisning er ikke let - men det er universiteternes vigtigste opgave og bør gå forud for universiteternes umiddelbare behov for løsning af kortsigtede forskningsopgaver. Stillingscirkulæret er en vigtig brik i denne udvikling. 
Frederik Voetmann Christiansen er lektor i Naturvidenskabsdidaktik ved Institut for

Farmaci ved Det Sundhedsvidenskabelige Fakultet, Københavns Universitet. Hans

forskning og undervisning er primaert inden for universitetspaedagogik og

uddannelsesforskning, natur- og sundhedsvidenskabelig didaktik, samt natur- og

sundhedsvidenskabelig videnskabsteori.

\section{Litteratur}

Aagard, K. (2011). Kampen om basismidlerne. Ph.d.-afhandling, Center for forskningsanalyse, Aarhus Universitet.

Bärenholdt, N. (2014). Markedsgørelsen af de danske universiteter 1970-2003 - Fra velfcerdsstat til konkurrencestat? Kandidatspeciale, Saxo-instituttet, Københavns Universitet.

Christiansen, F. V. \& Troelsen, R. P. (2016). Dokumentation af undervisningskompetencer - om brugen af undervisningsportfolio i og uden for adjunktuddannelsen. Dansk Universitetspaedagogisk Tidsskrift, 21.

Notat om stillingsstruktur (2013). Bilag 3.1 til Stillingsstruktur (2015).

Regeringen (2003). Nye veje mellem forskning og erhverv - fra tanke til faktura. Hentet 10/2 fra: http://ufm.dk/publikationer/2003/filer-2003/nye-veje-mellemforskning-og-erhverv-fra-tanke-til-faktura.pdf

Stillingsstruktur (1993). Cirkuloere om stillingsstruktur ved højere uddannelsesinstitutioner under Undervisningsministeriet, 2.4.1-1 og notat om stillingsstruktur for videnskabeligt personale med forsknings- og undervisningsopgaver ved de højere uddannelsesinstitutioner. Undervisningsministeriet, 2.4.1-21

Stillingsstruktur (2000). Stillingsstruktur ved universiteter m.fl. under Forskningsministeriet. Forskningsministeriet, 1.3.1-1, samt Notat om stillingsstruktur for videnskabeligt personale med forskningsopgaver og undervisningsopgaver ved universiteter m.fl. under Forskningsministeriet. Forskningsministeriet 1.3.1-21.

Stillingsstruktur (2004). Cirkulcere om stillingsstruktur for videnskabeligt personale ved universiteter og Videnskabsministeriets notat om stillingsstruktur ved universiteterne. Cirkulære af 22. december 2004. J.nr. 02-335-10. Perst. nr. 06404.

Stillingsstruktur (2007). Cirkulcere om stillingsstruktur for videnskabeligt personale ved universiteter og Videnskabsministeriets notat om stillingsstruktur ved universiteterne. Cirkulære af 13. juni 2007. J.nr. 06-335-21. Perst. nr. 055-07.

Stillingsstruktur (2015). Cirkulcere om protokollat om visse anscettelsesvilkår for videnskabeligt personale ved universiteter. CIR nr. 10578 af 18/09 2015.

Ståhle, B. (2003). Forskere søges -ansøgere mangler - forskerpersonale og forskerrekruttering på danske universiteter 1998-2000. Uni-C, København $\varnothing$. 
Ståhle, B. (2005). En forskerstab i forandring - forskerpersonale og forskerrekruttering på danske universiteter 2001-2003. Uni-C, København Ø.

Ståhle, B. (2007). Fornyelse i forskerstaben - forskerpersonale og forskerrekruttering på danske universiteter 2004-2006. Uni-C, København Ø.

Ståhle, B. (2011). En forskerstab i vaekst - forskerpersonale og forskerrekruttering på danske universiteter 2007-2009. Uni-C Statistik og analyse, København Ø.

Ståhle, B. (2014a). Videnskabeligt personale på universiteterne 2013. Statistiknotat, Uddannelses- og forskningsministeriet. URL: http://ufm.dk/forskning-oginnovation/statistik-og-analyser/forskere-ved-universiteterne/videnskabeligtpersonale-pa-universiteterne-2013-statistiknotat-1.pdf

Ståhle, B. (2014b). Forskerrekruttering på universiteterne 2011-2013. Statistiknotat, Uddannelses- og Forskningsministeriet. URL: http://ufm.dk/forskning-oginnovation/statistik-og-analyser/forskere-veduniversiteterne/forskerrekrutteringen-pa-universiteterne-2011-2013statistiknotat-2.pdf

Weiss, B. (1999) Frisk luft på universiteterne. Information, 2. december 1999. 